\title{
Faktor Penolakan Pembangunan Gereja Oleh Masyarakat di Kota Cilegon
}

\author{
Abdul Riansyah ${ }^{1}$ \\ Program studi Ilmu Pemerintahan, FISIP, UNTIRTA \\ abdulriyansah11@gmail.com \\ Mia Mulyani2 \\ Program studi Ilmu Pemerintahan, FISIP, UNTIRTA \\ miamlyni11@gmail.com \\ Muhamad Faisal AL-Giffari ${ }^{3}$ \\ Program studi Ilmu Pemerintahan, FISIP, UNTIRTA \\ faisalalgiffari18@gmail.com \\ Shidqi Fadhilah Akbar ${ }^{4}$ \\ Program studi Ilmu Pemerintahan, FISIP, UNTIRTA \\ shidqifadilaha@gmail.com \\ Siti Hulailah ${ }^{5}$ \\ Program studi Ilmu Pemerintahan, FISIP, UNTIRTA \\ hulailahsiti@gmail.com
}

E-ISSN (2721-0642)

Recieved:

January 262021

Revised:

April 22021

Accepted:

14 April 2021

Doi Number

https://doi.org/10.37950/ijd.v3i1.79

\begin{abstract}
This article contains multiculturalism in the city of Cilegon which does not work well because of discrimination which causes the struggle for the rights of Christians who are a minority in the city of Cilegon due to discrimination from the majority in the city of Cilegon who are Muslims. Therefore, there are many factors underlying the sense of intolerance that should not have occurred in Indonesia because it opposes the 1945 Constitution. This intolerance can be seen from the rejection of the construction of Christian Greja which is a place of worship that should exist in every region because it is one of the reflections of the 1945 Constitution. This conflict will also dissect this conflict by using the theory of identity politics, precisely the theory of Minority Rights in multicultural society proposed by Will Kymlicka. Therefore, many factors have become the author's curiosity about the intolerance and struggle for the rights of Christian minorities in the City of Cilegon.
\end{abstract}

Keywords: religious intolerance, the struggle for the rights, minorities 


\begin{abstract}
Abstrak
Artikel ini berisi tentang multikulturalisme yang ada di kota cilegon tidak berjalan dengan baik karena adanya diskriminasi yang menyebabkan perjuangan hak agama Kristen yang merupakan minoritas di kota cilegon karena adanya diskriminasi dari kaum mayoritas di kota cilegon yang beragama Islam. Maka dari itu banyak faktor yang melatar belakangi rasa intoleransi yang seharusnya tidak terjadi di Indinesia karena menentang UUD 1945. Intoleransi ini terlihat dari adanya penolakan pembangunan Greja Kristen yang merupakan tempat ibadah yang seharusnya ada di setiap daerah karena merupakan salah satu dari pencerminan UUD 1945. Kasus ini juga akan membedah konflik ini dengan menggunakan teori politik identitas tepatnya teori Hak Minoritas dalam masyarakat multicultural yang dikemukakan oleh Will Kymlicka. Maka dari itu banyak faktor yang menjadi rasa penasaran penulis mengenai intolernsi dan perjuangan hak minoritas Agama Kristen di Kota Cilegon.
\end{abstract}

Kata Kunci: intoleransi beragama, perjuangan hak, minoritas

\title{
Pendahuluan
}

Multikultural dalam hal umat Beragama merupakan salah satu dari ciri khas negara Indonesia dimana perbedaan lain tersebut seperti suku dan ras merupakan bagian dari masyarakat Indonesia itu sendiri dimana sudah berdiri sebelum bangsa Indonesia terbentuk. Suatu negara pasti nya memiliki agama yang berbeda-beda, salah satunya yaitu negara Idonesia. Negara Indonesia merupakan negara yang memiliki berbagai etnis, budaya dan agama. Di Indonesia sendiri warga negara nya mayoritas agama Islam sebesar 85\%, akan tetapi Indonesia memberikan kebebasan kepada warga negara nya untuk berhak memilih agama nya sendiri, karena Indonesia merupakan salah satu negara yang pluralis.

Tetapi dalam hal agama di Indonesia sering terjadi konflik-konflik perbedaan agama yang dianut nya, yang mana masyarakat mayoritas beragama Islam ini tidak menginginkan didirikan nya sebuah tempat beribadah atau tempat apapun yang berhubungan dengan agama lain salah satu nya yaitu pembangunan ibadah agama Kristen, sehingga dalam konflik ini adanya hak-hak kaum minoritas yang tidak terpenuhi seperti yang terjadi di kelurahan Citangkil Kota Cilegon Provinsi Banten, pada konflik yang terjadi di Desa Citangkil Kota Cilegon ini bahwasanya kaum mayoritas Islam di Desa Citangkil ini tidak menginginkan adanya pembangunan ibadah agama Kristen. Dari data BPS pada tahun 2013 kota cilegon memiliki warga sebanyak 335.913 jiwa, yang mayoritas agama islam nya yaitu sebanyak 97.64\%, sedangkan agama lain di kota cilegon adalah sebanyak $2.36 \%$.

Dari apa yang kita ketahui bahwa hal tersebut bertentangan dengan Pancasila sebagai landasan dasar negara ini berdiri, yaitu sila pertama dan sila ke lima yang berbunyi (1.Ketuhanan yang maha Esa \& 5.Keadilan sosial bagi seluruh rakyat 
Indonesia). Tentu saja karena masyarakat Indonesia yang beragama seperti agama yang berbeda mereka dianjurkan untuk menjalankan kewajiban agamanya yaitu ibadah, salah satu faktor penting mereka untuk melaksanakan ibadahnya yaitu dengan adanya fasilitas atau tempat ibadah mereka umat Kristen yaitu Gereja. Pada konflik ini juga bukan hanya melanggar atau bertentangan dengan Pancasila saja, akan tetapi bertentangan dengan peraturan bersama Menteri Agama No.9 dan Menteri Dalam Negeri No.8 Tahun 2006 tentang pedoman pelaksanaan tugas kepala daerah dalam pemeliharaan kerukunan umat beragama dan pendirian tempat ibadah. Konflik konflik atau permasalahan yang terjadi terkait hak kaum minoritas yang tidak terpenuhi karena penolakan dari kaum mayoritas (Riswanda et al., 2020) tidak dapat dilepaskan dari peran yang sangat penting yaitu adanya peran Forum Kerukunan Umat Beragama, namun masyarakat mayoritas Islam di Kota Cilegon menentang hal tersebut dikarenakan hal itu dapat mengganggu kegiatan umat Muslim di sana.

Maka dari itu kami sebagai penulis ingin membedah secara mendalam lagi terkait apa saja alasan umat beragama dikota cilegon, dan hak-hak kaum minoritas yang bukan beragama Islam yang tidak diperbolehkan untuk membangun tempat ibadahnya dikarenakan alasan dapat mengganggu umat Muslim? Apakah hanya itu saja yang menjadi alasan tidak diperbolehkan nya pembangunan tempat beribadah selain tempat beribadah agama Islam?. Dan kami juga ingin membedah bagaimana kaum minoritas umat Kristen di Kota Cilegon ini dalam memperjuangkan hak-hak kaum minoritas nya terutama dalam hak beribadah yang mana beribadah ini merupakan hal yang harus dilakukan oleh setiap umat beragama. Disini kami juga akan membedah konflik ini dengan menggunakan teori politik identitas tepatnya teori Hak Minoritas dalam masyarakat multicultural yang dikemukakan oleh Will Kymlicka (Simamora et al., 2019). Dengan teori ini kami akan jadikan sebagai pisau atau alat untuk melakukan analisa yang dapat membantu dalam penelitian literatur review ini dengan hanya mengandalkan artikel berita jurnal.

\section{Kerangka Teori}

Kerangka teoritis merupakan sebuah teori-teori yang di identifikasi lal yang dijadikan sebagai salah satu acuan landasan berfikir untuk melaksanakan sebuah penelitian atau dengan maksud lain yaitu untuk mendeskripsikan suatu kerangka refrensi atau teori yang akan digunakan untuk membahas permasalahan. Seperti yang dikatakan oleh Jujun S.Soerya Sumantri mengatakan bahwa pada dasarnya memecahkan masalah ialah dengan penggunaan pengetahuan ilmiah yang dijadikan dasar argumenn untuk meneliti persoalan agar peneliti menemukan sebuah jawban yang dapat diandalkan.

Penelitian ini membahas teori hak minoritas Will Kymlicka. Pertanyaan yang berusaha dicari dan menemukan sebuah jawaban dalam apa yang di teliti ini antara lain ialah merupakan gagasan tentang hak minoritas, gagasan tentang masyarakat multikultural, dengan sudut pandangan Kymlicka mengenai sebuah hak minoritas dalam masyarakat multikultural. Dalam Penelitian disini sang peneliti akan membahas tentang hak minoritas Will Kymlicka yang dilihat dari sudut pandang filsafat politik. 
Menurut Kymlicka, hak seorang individu sangat berhubungan dengan hak sebuah kelompok ketika hak sebuah kelompok itu tidak dapat dipenuhi maka hak individu nya juga tidak akan terpenuhi, seperti ketika hak kaum minoritas agama Kristen tidak terpenuhi untuk beribadah maka hak setiap individu nya juga tidak akan terpenuhi untuk melaksanakan ibadahnya, sehingga hak kaum minoritas harus diperjuangkan. Pandangan kymlicka tentang hak minoritas dalam masyarakat multikultural, yaitu membahas hak-haknya melalui peninjauan filsafat politik. teori yang di kembangkan oleh kymlicka merupakan basis-basis teori liberal, karenanya hak minoritas yang masuk dalam kategori hak kelompok yang ada pada teori Kymlicka tidak menentang landasan dasar liberalism (Hikmawan, 2020). Wujud hak minoritas yang diberikan oleh Kymlicka seperti multikulturarisme imigrasi dan pemberian hak kepada perwakilan minoritas yang tidak masuk kategori. Dengan lahirnya paham multikulurarisme didasari oleh kebutuhan masyarakat akan adanya pengakuan kepada masyarakat minoritas terhadap akan adanya ragam budaya yang salah satunya berada dari unsur budaya yang ada di masyarakat (Hikmawan, 2017).

Multikulturalisme ini harus di sadari oleh kita sebagai suatu ideologi untuk menjadi suatu wadah yang akan meningkatkan akan kesadaran dan penghargaan terhadap kesetaraan sesama manusia dan mewujudkanya melalui tradisi sosial yaitu budaya sebagai pemandu kehidupan manusia sehari-hari. Pengakuan akan sesama manusia di Indonesia telah di jadikan sebagai acuan yaiu seperti adanya bhineka tunggal ika yang artinya, berbeda-beda tapi tetap satu. Hal ini mengungkapkan bahwa ini adalah sebuah kemauan yang kuat untuk manusia untuk mengakui adanya perbedaan serta memelihara kesatuan serta keragaman. Keragaman dan perbedaan perlu dipahami dan dihargain sebagai realitas kehidupan sehari-hari. Banyaknya problem yang ada di Indonesia akan masalah minoritas, perlu adanya kajian-kajian oleh pemerintah untuk menentukan dan menyesuaikan secara normatif model multikulturarisme apa yang akan dijadikan acuan untuk negara ini.

\section{Metode Penelitian}

Pada dasarnya metode penelitian merupakan suatu cara bagimana seorang peneliti dapat menyusun karya ilmiah dengan baik, dimana metode penelitian dapat menganalisis sebuah data dan informasi serta menyusun penelitian sesuai dengan topik penelitian. Maka dalam penelitian ini menggunakan teknik analisis dengan pendekatan kualitatif. Dimana pendekatan kualitatif merupakan proses analisis data yang berupa kata-kata atas permasalahan yang dibahas dalam penelitian ini. Penelitian dengan menggunakan metode kualitatif memiliki kelebihan dalam membangun dan mengkonstruksikan realita sosial, makna buday, dan berfokus pada proses interaktif dari sebuah peristiwa. Dalam mencari data pada penilitian ini yaitu menggunakan metode studi literatur dan dialog menggunakan media sosial. Dimana nantinya data yang diperoleh dari metode tersebut akan dianalisis dengan menggunakan teknik analisis kualitatif deskriptif. Analisis kualitatif deskriptif berkaitan dengan data yang berupa kata atau kalimat yang dihasilkan dari objek penelitian serta berkaitan dengan kejadian yang melingkupi objek penelitian. 
Menurut Bogdan dan Biglen (dalam Moleong, 2009:248) mengatakan bahwa analisis data kualitatif merupakan suatu upaya yang dilakukan peneliti untuk mengolah data, mengorganisasikan data, memilah-milahnya menjadi satuan yang bisa diolah, mensintesiskan, mencari, dan menemukan pola yang penting dari apa yang dipelajari dan diceritakan kepada orang lain.

Penelitian ini dimulai dengan melakukan laporan penelitian awal, policy brief, dan sekarang dengan hasil akhir berupa jurnal penelitian. Dimana dalam hal ini, penulis mengambil fokus dan lokus penelitian pada permasalahan soal pendirian gereja di Kota Cilegon. Pemilihan fokus dan lokasi tersebut karena melihat dari kondisi konflik umat beraga di Kota Cilegon terutama pada perjuangan umat kristiani yang berusaha memperjuangkan hak beribadahnya dan penolakan umat muslim atas pendirian gereja di Kota Cilegon. yang sudah cukup maju baik dalam bidang infrastruktur dan pendidikan masyarakatnya. Maka berdasarkan hal tersebut nantinya penulis akan melihat apa saja yang menjadi faktor penyebab dan bagaimana sikap umat kristiani dan muslim di Kota Cilegon. Oleh karena itu dengan menggunakan teknik analisi atau metode kualitatif deskriptif, penulis akan mencoba menganalisis permasalahan tersebut dalam hasil dan pembahasan. Metode ini akan membedah persoalan tersebut untuk nantinya diambil kesimpulan atas hasil yang diperoleh dalam tulisan ini.

\section{Hasil Dan Pembahasan Hak Minoritas Agama}

Pada sebuah negara pasti memiliki kaum mayoritas dan kaum minoritas. Kaum mayoritas adalah sejumlah orang-orang yang mendominasi suatu negara atau daerah tersebut dengan mempunyai ciri-ciri yang sama seperti agama, suku, sosial dan budaya. Sedangkan kaum minoritas adalah orang atau kelompok yang memiliki jumlah nya lebih sedikit dibandingkan dengan kaum mayoritas, karena dengan jumlah orang atau kelompok nya lebih sedikit sehingga kaum minoritas terkadang selalu didiskriminasi kan atau selalu terkalahkan oleh kaum mayoritas, akan tetapi kaum minoritas memiliki hak yang sama dengan kaum mayoritas dalam sebuah negara.

Ketika membahas hak-hak kaum minoritas seperti hak dalam sosial, politik, dan kebebasan beragama itu termasuk kedalam hak asasi manusia (HAM) yang tidak bisa diganggu gugat ataupun ditawar (non-derogable rights). Perlindungan dalam hak asasi manusia sudah termaktub dalam piagam PBB yang sesuai dengan pasal 27,28,29,30, dan pasal 31 UUD NRI 1945.

Dalam hak-hak kaum minoritas pada hal kebebasan beragama sudah berjalan dengan baik pelaksanaan nya, tetapi masih terjadi konflik antara kaum minoritas dan kaum mayoritas seperti yang terjadi di kelurahan Citangkil Kota Cilegon Banten. Yang mana konflik ini terjadi ketika akan dibangun tempat beribadah non islam yaitu gereja, kaum mayoritas merasa terganggu ketika tempat ibadah gereja dibangun di daerah mereka tersebut.

Menurut Kymlicka, hak seorang individu sangat berhubungan dengan hak sebuah kelompok ketika hak sebuah kelompok itu tidak dapat dipenuhi maka hak 
individu nya juga tidak akan terpenuhi, seperti ketika hak kaum minoritas agama Kristen tidak terpenuhi untuk beribadah maka hak setiap individu nya juga tidak akan terpenuhi untuk melaksanakan ibadahnya, sehingga hak kaum minoritas harus diperjuangkan. Dalam kasus ini bisa dikatakan bahwasan nya hak-hak kaum minoritas ini tidak terpenuhi karena untuk mendirikan tempat ibadah gereja saja tidak bisa dibangun di Kota Cilegon, masyarakat kaum minoritas non Islam Kota Cilegon ketika ingin beribadah saja harus menempuh perjalanan yang cukup jauh, harus ke Kota Serang ketika ingin melaksanakan ibadahnya.

\section{Intoleransi Agama di Cilegon}

Intoleransi merupakan suatu hal yang tidak di inginkan semua manusia orang yang menginginkan hidup damai karena intoleransi merupakan sikap dari perwujudan negative dari perasangka yang buruk atau berlebihan terhadap suatu kelompok maupun individu. Intoleransi dapat berupa kebencian terhadap Suku, Ras dan bahkan Agama. Menurut Hunsberger (1995). Intoleran adalah Tindakan negatif yang dilatar belakangi oleh simplikasi-palsu "Prasangka Berlebihan". Prasangka seperti ini memiliki tiga komponen yaitu; (1) Komponen kognitif mencakup stereotip terhadap "kelompok luar darinya yang direndahkan"; (2) Komponen afektif yang berwujud sikap muak atau rasa tidak suka yang berlebihan (mendalam) terhadap kelompok luar; dan (3) Komponen Tindakan negatif terhadap anggota kelompok luar, maupun dari interpersonal atau bahkan dalam hal kebijakan sosial-politik. (Hunsberger's 1995:113-29).

Dalam kasus ini sikap intoleransi yang terlihat dari umat Islam di Kota Cilegon yang menunjukan adanya sikap tidak menyukai adanya keberagaman karena adanya penolakan dari kaum mayoritas yaitu umat beragama Islam terhadap kaum minoritas beragama Kristen dalam upaya pembangunan tempat ibadah. Karena pada dasarnya dalam UUD 1945 saja menganjurkan setiap warga negara bebas memilih agamanya dan menjalankan kewajiban beragamanya dan salah satunya yaitu mendirikan tempat ibadah, karena tempat ibadah merupakan tempat dimana seluruh umat yang menganut agama tertentu berkumpul karena di yakini memiliki nilai atau pahala lebih jika beribadah di tempat ibadah. Begitu pula umat Kristen di Cilegon, mereka seharusnya memiliki hak yang sama dalam menunaikan kewajiban mereka untuk beribadah di Rumah Ibadah mereka yaitu Greja dimana seharusnya juga mereka leluasa untuk beribadah setiap waktu dimana mereka tidak memiliki cukup waktu untuk beribadah ke Greja yang bertempat di Kota Serang walaupun difasilitasi dalam hal transportasi namun, hanya dihari-hari tertentu seperti hari Minggu.

Dari komponen teori pertama dari Hunsberger yang mengatakan bahwa adanya sikap merendahkan, benar adanya karena dari hasil sumberdata yang didapat yang berupa wawancara bahwa mereka yang melakukan penolakan merasa bahwa Umat Islam adalah Agama yang sempurna,dan agama lainnya tidak sempurna, namun perlu di kaitkan Kembali bahwa pernyataan ini sudah jelas merupakan sikap intoleran dan adanya sikap arogansi karena adanya penolakan tersebut saja sudah termasuk kedalam diskriminasi terhadap minoritas agama Kristen dan melanggar UUD 1945 juga seperti yang disebutkan oleh Kimlycka yaitu adanya perjuangan hak kaum minoritas dalam 
pembuatan tempat ibadah tersebut. namun dalam komponen dua dalam teori Hunsberger berdasarkan pendapat dari narasumber yaitu adanya faktor sejarah dimana padam masa penjajahan Belanda di Indonesia yang kebanyakan dari tentara atau orang belanda merupakan umat Kristen dan melakukan pembunuhan terhadap Kiya'i atau ulama di Cilegon pada masanya. Namun dalam komponen ke-3 hanya adanya SK Bupati Serang yang selalu dijadikan sebagai alasan penolakan pembangunan Greja di Kota Cilegon oleh masyarakat setempat. Sudah dipastikan kaum mayoritas Kota Cilegon kurang dalam hal toleransi jika dilihat dari pandangan teori Hunsberger dan Kimlycka.

\section{Pembangunan Gerja di Cilegon}

Pembangunan rumah ibadah bagi non muslim di kota cilegon sudah menjadi hal yang kontroversial di berbagai masyarakat. Walaupun hal ini menjadi hal polemik bagi masyarakat, akan tetapi dari pihak kementerian agama kota cilegon mengatakan, kebebasan beragama merupakan hak setiap masyarakat, namun ia mengatakan bawha fasilitas keagamaan pun merupakan tanggung jawab negara. "justru negara itu harus memfasilitasi umat beragama", ujar Mahmudi selaku dari pihakt kementerian agama kota Cilegon. Untuk pembangunan rumah ibadah non muslim ini perlu disesuaikan oleh aturan, agar dalam pembangunannya tidak terjadi penyangkalan oleh masyarakat setempat.

Penolakan atau tidak diterimanya rumah ibadah ini telah menjadi cerita yang sering didengar olah masyarakat dari waktu ke waktu. Dengan berbagai macam alesan yang didapatkan seperti tidak memiliki izin serta tidak sesuai aturan. Hal ini kerap dijadikan pembenaran oleh pihak mayoritas untuk melakukan tindakan-tindakan yang intoleran. Beberapa peraturan daerah yang diskriminatif serta pemerintah daerah yang tak berpengaruh terhadap masyarakt yang intoleran menjadikan kaum minoritas semakin menyudut.

Menurut Peraturan Bersama Menteri Agama dan Menteri Dalam Negeri Nomor 9 Tahun 2006/ Nomor 8 Tahun 2006, kerukunan umat beragama adalah keadaan hubungan sesama umat beragama yang dilandasi toleransi, saling pengertian, saling 17 menghormati, menghargai kesetaraan dalam pengamalan ajaran agamanya dan kerjasama dalam kehidupan bermasyarakat, berbangsa dan bernegara di dalam Negara Kesatuan Republik Indonesia berdasarkan Pancasila dan Undang-Undang Dasar Negara Republik Tahun 1945.

Dalam peraturan di atas, daerah cilegon memiliki suatu organisasi yang bernama FKUB (forum kerukunan Umat beragama). peran FKUB dalam organisasi yaitu menjalankan tugas dan fungsinya sebagai menjaga pentingnya kerukunan yang ada. Pada peran yang telah dilakukan FKUB kota cilegon dalam penutupan rumah ibadah sudah efektif dan baik, karna selama permasalahan ini tidak ada pihak yang dirugikan dan dapat diselesaikan.

Dalam melaksanakan peraturan bersama menteri agama no. 9 dan menteri dalam negeri no. 8 tahun 2006, peran FKUB ini sangat penting dalam menjaga kerukunan serta selalu berusaha melaksanakan apa yang tertua dalam peraturan 
tersebut. Dalam hal pembangunan ini, banyaknya masyarakat-masyarakat yang terganggu serta merasa resah dengan adannya tempat ibadah Kristen di kota cilegon.

\section{Penolakan dari pembangunan geraja di Cilegon}

Banyak hal yang melatarbelakangi dari fenomena penolakan masyarakat mayoritas terhadapat masyarakat minoritas di Kota Cilegon. Dalam hal ini terjadi sebuah sentimen umat beragam di kota cilegon yaitu antara umat islam dan umat kristiani di Kota Cilegon. Masalah tersebut sebetulnya memiliki beberapa faktor yang menjadi penyebab masyarakat menolak dan ada beberapa faktor juga yang membut umat kristiani terus memperjuangkan haknya. Berdasarkan undang-undang sebetulnya negara terlah menjamin kegiatan beribadah di negara ini termasuk oleh umat kristianin. Akan tetapi memang ada masalah yang unik telah terjadi di Kota Cilegon. Dimana permasalahan tersebut terletak pada bagaimana sikap negara (pemerintah Kota Cilegon) dalam mengatasi permasalahan tersebut.

Maka berdasarkan permasalahan-permasalahan yang terjadi sebagian besar terletak pada latar belakang sejarah yang pernah terjadi di Kota Cilegon. Dimana pada saat masa penjajahan oleh kolonial Belanda di Kota Cilegon yang menindah masyarakat cilegon terutama kepada para ulama dan kiaya di Kota Cilegon. Hal tersebut membawa trauma yang mendalam oleh masyarakat di Kota Cilegon. Oleh karena itulah maka dikeluarkan wasiat ulama Banten tentang larangan pendirian tempat ibadah bagi umat kristiani di Kota Cilegon. Untuk merespon hal tersebut maka keluarlah Surat Keputusan (SK) Gubernur Jawa Barat, karena saat itu masih bagian dari provinsi Jawa Barat. Akan tetapi karena Cilegon bukan lagi bagian dari Jawa Barat maka secara otomatis SK tersebut sudah tidak lagi berlaku. Akan tetapi memang beberapa kelompok masyarakat tetap menjadikan SK tersebut sebagai alasan untuk tetap menolak. Sudah sangat lama persoalan ini terus terjadi, dimana hal membuat tidak adanya kebebasan bagi umat beragama, terutama oleh umat kristiani di Kota Cilegon. Sejak tahun 1995, ada sekitar lebih dari 10 kali tindakan demonstrasi oleh masyarakat mayoritas umat islam di Kota Cilegon untuk menuntut penutupan gereja bagi umat kristiani

\section{Kesimpulan}

Pada artikel ini dapat disimpulkan bahwa pada kasus konflik penolakan pembangunan gereja di Kelurahan Citangkil Kota Cilegon ini memang benar adanya, hal tersebut dilatarbelakangi oleh adanya sikap tidak suka antara kaum mayoritas yaitu agama Islam dengan kaum minoritas yaitu agama Kristen, sehingga ketika ingin dibangun tempat ibadah agama Kristen ini tidak diperbolehkan oleh kaum mayoritas. Berdasarkan hasil wawancara yang dilakukan kepada kaum minoritas agama Kristen juga terjadi ketika kaum mayoritas agama Islam menganggap kalau agama Islam lebih baik dibandingkan agama lain nya sehingga konflik itu terjadi. Akan tetapi konflik yang terjadi ini sudah melanggar UUD 1945 yang membebaskan setiap warga negara nya untuk beragama, tetapi di Kota Cilegon ini masih saja melakukan diskriminasi terhadap kaum minoritas. 


\section{Tentang Penulis}

Abdul Riyansah adalah mahasiswa Program Studi Ilmu Pemerintahan, Fisip, Untirta. Ketertarikan riset pada bidang Dinasti Politik, Partai Politik, dan Kepemimpinan Pemerintahan.

Mia Mulyani adalah mahasiswa Program Studi Ilmu Pemerintahan, Fisip, Untirta. Ketertarikan riset dalam bidang Politik Dinasti dan Pelayanan Pemerintahan

Muhamad Faisal AL-Gifari adalah mahasiswa Program Studi Ilmu Pemerintahan, Fisip, Untirta. Ketertarikan riset pada bidang Kepemimpinan Pemerintah, dan Inovasi Goverment

Shidqi fadhilah akbar adalah mahasiswa Program Studi Ilmu Pemerintahan, Fisip, Untirta. Ketertsrikan pada riset ada pada bidang Identitas Politik, Identitas Sosial, dan Politik Dinasti.

Siti Hulailah adalah mahasiswa Program Studi Ilmu Pemerintahan, Fisip, Untirta. Ketertarikan riset pada Politik dinasti dan Politik uang dalam pemilu atau pun Pilkades.

\section{Ucapan Terimakasih}

Penulis mengucapkan syukur kepada Allah SWT atas limpahan nikmat sehatNya, baik itu berupa sehat jasmani dan rohani, sehingga penulis mampu untuk menyelesaikan penulisan penelitian mata kuliah PIDM dengan tema "Faktor Penolakan Pembangunan Gereja Oleh Masyarakat Di Kota Cilegon" Penulis tentu menyadari bahwa Tulisan ini masih jauh dari kata sempurna dan masih banyak terdapat kesalahan serta kekurangan di dalamnya. Untuk itu, penulis mengharapkan kritik serta saran dari pembaca untuk Tulisan ini, supaya tulisan ini nantinya dapat menjadi tulisan yang lebih baik lagi. Demikian, dan apabila terdapat banyak kesalahan pada tulisan jurnal ini penulis mohon maaf yang sebesar-besarnya. Penulis juga mengucapkan terima kasih kepada semua pihak khususnya kepada Dosen Pembimbing kami Bapak M. Dian Hikmawan yang telah membimbing kami dalam menulis Jurnal ini. Demikian, semoga Jurnal ini dapat bermanfaat.

\section{Referensi}

Aji, Ahmad Mukri. 2014. Identifikasi Potensi Konflik Pra dan Pasca Pendirian Rumah Ibadah Di Indonesia Dan Upaya Untuk Mengatasinya (Studi Kasus Di Kota Dan Kabupaten Bogor). Jurnal Ilmu Syariah. Vol. 2 No. 1 Halaman 1-16

Balai Litbang Agama Jakarta. 2015. Konflik Dan Penyelesaian Pendirian Rumah Ibadat. Jakarta: Kemenag Litbang

Fahmi. 2017. "Penolakan Masyarakat Kota Cilegon Terhadap Rumah Ibadah Umat Kristiani". Diakses pada 25 Desember 2020

Hartani, Mallia Dan Nulhakim, S. Akhmad. 2020. Analisis Konflik Antar Umat Beragama Di Aceh Singkil. Jurnal Kolaborasi Resolusi Konflik. Volume 2, Nomor 2, Halaman 93-99 
Hikmawan, M. D. (2017). Pluralisme Demokrasi Politik di Indonesia. Journal of Governance, 2(2), 223-247. https://doi.org/http://dx.doi.org/10.31506/jog.v2i2.2678

Hikmawan, M. D. (2020). Consensual Democracy: A Challenge for Differentiated Citizenship. In International Journal of Innovation, Creativity and Change. www.ijicc.net (Vol. 11, Issue 2). www.ijicc.net

JL. 2020. "Kemenag Kota Cilegon Izinkan Pendirian Gereja Asalkan Sesuai Aturan". Diakses pada 24 Desember 2020

Jamaludin, A. Nasrullah. 2018. Konflik Dan Integrasi Pendirian Rumah Ibadah Di Kota Bekasi. Jurnal Socio-Politica. Volume 8, Nomor 2, Halaman 227-238

Kymlicka, W. (1995). Multicultural Citizenship A Liberal Theory of Minority Rights. Oxford University Press. Inggris

Kymlicka, W. (2011). Multicultural Odysseys: Navigating the New International Politics of Diversity. Oxford University Press. Inggris

Melekpolitik.com. 2019. "Miris! Minoritas Masih Sulit Mendirikan Tempat Ibadah". Diakses pada 24 Desember 2020

Moleong, J. Lexy. 2009. Metodologi Penelitian Kualitatif. Bandung: PT. Remaja Rosdakarya

Lori. 2019. "Selama Setahun, Intoleransi di Indonesia Sudah Mencapai 31 Kasus, Mengkhawatirkan!". Diakses pada 24 Desember 2020

Riana, Fiski dan Dewi Nurita. 2020. "Rumah Ibadah Belenggu Mayoritas". Diakses 24 Desember 2020

Riswanda, M., Hikmawan, D., Ramadhan, G., \& Nurrohman, B. (2020). Making sense of the politics of recognition: Indicators of religious tolerance in Banten, Indonesia. International Journal of Engineering Research and Technology, 13(11).

Rizal. 2018. "FKUB : Sebaiknya Tak Ada Gereja di Cilegon Demi Jaga Kerukunan”. Diakses pada 25 Desember 2020.

Simamora, A. R., Hamid, A., \& Hikmawan, M. D. (2019). Diskriminasi Terhadap Kelompok Minoritas Jemaat Ahmadiyah Indonesia (JAI) di Tangerang Selatan. International Journal of Demos, 1(1), 19-37. http:/ / hk-publishing.id/ijd-demos

www.uii.ac.id. 2020. Perlindungan Hak-Hak Minoritas dan Kebebasan Beragama Tak Boleh Dikompromikan. Diakses pada 26 Desember 2020. 